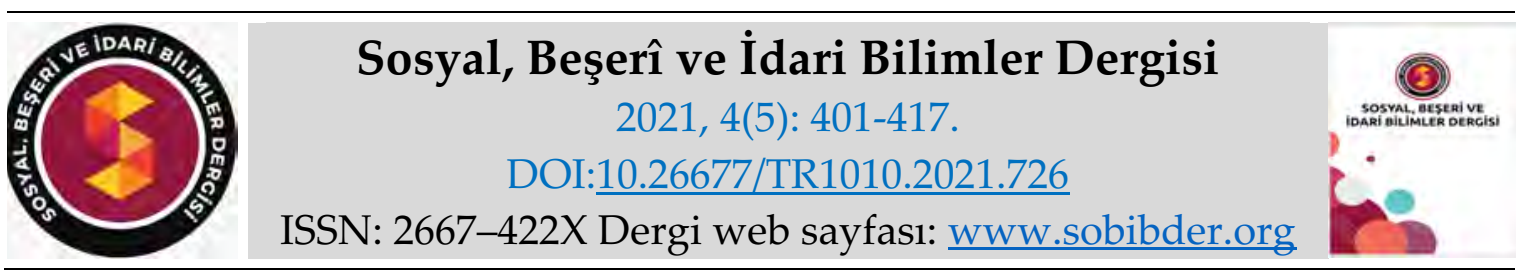

ARASTTIRMA MAKALESI

\title{
Yerli Turistlerin Algılarına Göre Ahilik İlkeleri: İstanbul Kapalıçarşı Örneği
}

Dr. Öğr. Üyesi Ozan ÇATIR, Uşak Üniversitesi, Ulubey Meslek Yüksekokulu, Uşak, e-posta: ozan.catir@usak.edu.tr

ORCID: https://orcid.org/0000-0003-3168-7338

Öğr. Gör. Kenan SAKALLI, Uşak Üniversitesi, Ulubey Meslek Yüksekokulu, Uşak, e-posta: kenan.sakalli@usak.edu.tr

ORCID: https://orcid.org/0000-0002-8077-5660

Öz

Selçuklu ve Osmanlı döneminde sosyal ve ekonomik hayatı, felsefesi ve faaliyetleriyle düzenleyen Ahilik anlayışı özelde esnaf ve sanatkârların, genelde ise tüm toplumun gelişmesine katkı sağlayan önemli kurumlardan biridir. Günümüz esnaf ve sanatkârlarının uyguladığı birçok uygulama Ahilik geleneğinin devamı şeklinde kendini göstermektedir. Ama zamanla Ahilik anlayışının ilkeleri terk edilmiş ve kapitalist düzenin getirmiş olduğu ilkeler benimsenmiştir. Çalışmanın amacı, turizm açısından büyük bir öneme sahip olan İstanbul Kapalıçarşı Esnaf ve Sanatkârlarının ahilik ilkelerine sahip olma durumlarını yerli turistlerin Tripadvisor seyahat sitesinde yapmış oldukları yorumlara göre değerlendirmektir. Çalışmada nitel araştırma yaklaşımından yararlanılmıştır. Tripadvisor'da kullanıcılar tarafından oluşturulan 727 yorum incelenmiş; esnaf, sanatkâr ve satıcı anahtar kelimelerinin geçtiği 47 yorum içerik analizi ile incelenmiştir. Çalışma sonucunda İstanbul Kapalıçarşı Esnaf ve sanatkârlarının Ahilik ilkelerine sahip olma konusunda bazı problemlerin olduğu ifade edilebilir.

Anahtar Kelimeler: Esnaf ve Sanatkârlar, Ahilik İlkeleri, İstanbul Kapalıçarşı, Turist, Turizm. Makale Gönderme Tarihi: 11.02 .2021

Makale Kabul Tarihi: 03.05.2021

\section{Önerilen Atıf:}

Çatır, O. ve Sakallı, K. (2021). Yerli Turistlerin Algılarına Göre Ahilik İlkeleri: İstanbul Kapalıçarşı Örneği, Sosyal, Beşeri ve İdari Bilimler Dergisi, 4(5): 401-417.

(c) 2021 Sosyal, Beşerî ve İdari Bilimler Dergisi. 


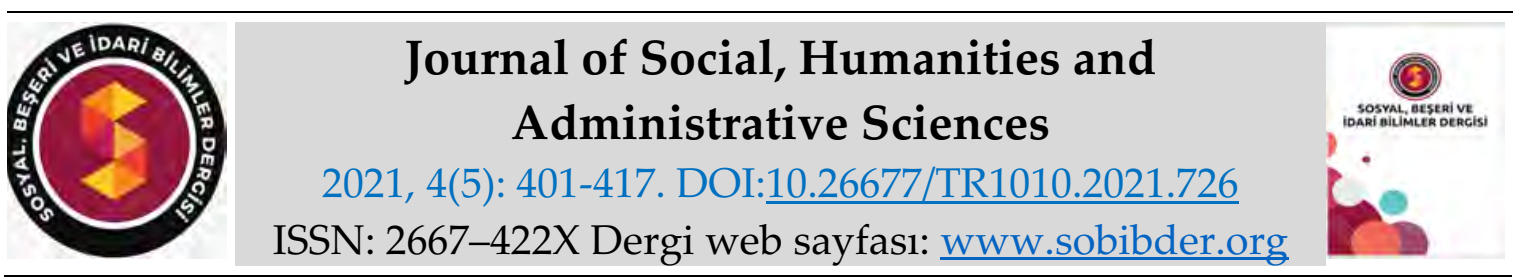

RESEARCH PAPER

\title{
Akhi Principles According to the Perceptions of Local Tourists: The Case of İstanbul Grand Bazaar
}

Assistant Prof. Dr. Ozan ÇATIR, Uşak University, Ulubey Vocational School, Uşak, e-mail: ozan.catir@usak.edu.tr

ORCID: https://orcid.org/0000-0003-3168-7338

Lecturer Kenan SAKALLI, Uşak University, Ulubey Vocational School, Uşak, e-mail: kenan.sakalli@usak.edu.tr

ORCID: https://orcid.org/0000-0002-8077-5660

\begin{abstract}
The understanding of Akhi, which regulates social and economic life with its philosophy and activities in the Seljuk and Ottoman periods, is one of the important institutions that contributed to the development of tradesmen and craftsmen in particular and the whole society in general. Many practices implemented by today's craftsmen and craftsmen show themselves as the continuation of the Akhi tradition. But in time, the principles of the Akhi understanding were abandoned and the principles introduced by the capitalist order were adopted. The aim of the study is to evaluate the status of the İstanbul Grand Bazaar Tradesmen and Craftsmen, which has a great importance in terms of tourism, the principles of akhism according to the comments made by local tourists on the Tripadvisor travel site. Qualitative research approach was used in the study. 727 comments created by users on Tripadvisor were examined, 47 comments with the keywords of tradesmen, craftsmen and sellers were analyzed with content analysis. As a result of the study, it can be stated that İstanbul Grand Bazaar Tradesmen and craftsmen have some problems about having Akhi principles.
\end{abstract}

Keywords: Tradesmen and Craftsmen, Akhism Principles, İstanbul Grandbazaar, Tourist, Tourism.

Received: 11.02 .2021

Accepted: 03.05.2021

\section{Suggested Citation:}

Çatır, O. and Sakallı, K. (2021). Akhi Principles According to the Perceptions of Local Tourists: The Case of İstanbul Grand Bazaar, Journal of Social, Humanities and Administrative Sciences, 4(5): 401-417.

(C) 2021 Sosyal, Beşerî ve İdari Bilimler Dergisi. 


\section{Gíriş}

Kapitalist dünyanın dayatmalarıyla oluşan modern işletmecilik anlayışı, işletmelerin daha fazla kâr etmesi, insanların uzun süreler çalışması, ihtiyaçtan fazla üreterek, bu ürünlerin satılması için yeni pazarların oluşturulması ve insanların gerçek ihtiyaçları dışındaki ürünlere karşı da istek duymalarını sağlayarak tüketim odaklı bir toplum oluşturmuştur. Modern işletmecilik, verimlilik ve performans üzerinde odaklanmış, insanı temel alan anlayışın dışında materyalist bir bakış açısı kazanmıştır. Yeni yönetim anlayışları her ne kadar insana önem verilmesi gerektiğini söylese de gelişmekte olan ülkelerde bu durum emek sömürüsü üzerinden yürütülmektedir. Hem Anadolu Selçuklu hem de Osmanlı Devleti döneminde etkin olan Ahilik teşkilatında ise, insanı temel alan ahlaki değerleri önemseyen, adalete değer veren ve kaliteli ürünlerin ortaya çıkarılmasını sağlayan felsefeler benimsenmiştir. Ahilik, rekabeti değil dayanışmayı destekler. Bireysel zenginliğin yerine, toplumsal olarak zenginleşmeye yöneltir. Bugün unutulmuş değerler olan ahilik ilkeleri, modern dünyanın dayatmalarından uzakta mutlak başarıyı yakalayabilecek bir model olabilir.

Çalışmanın problemini ifade edebilmek için çalışmanın neden gerçekleştirildiği, literatür ve uygulamada hangi boşluğu dolduracağı açıklanmalıdır. Yukarıda konuları verilen araştırmalar incelendiğinde Ahilik ilkelerine sahiplik düzeyinin belirlenmesine yönelik az sayıda çalışmaya rastlanmıştır (Cihangir ve Karakaya 2016). Bu konudaki kuramsal boşluğu doldurması anlamında çalışmanın önemli olduğu düşünülmektedir. Çalışmanın amacı, Ahilik anlayışından yola çıkarak, Turizm açısından büyük bir öneme sahip olan İstanbul Kapalıçarşı Esnaf ve Sanatkârlarının ahilik ilkelerine sahip olup olmadıklarını Tripadvisor seyahat sitesi kullanıcı yorumlarını inceleyerek tespit etmektir. Bu amacı gerçekleştirmek için Ahilik konusunda yapılan çalışmalar incelenmiş ve ahiliğin temel ilkeleri ortaya çıkarılmıştır. Bu ilkeler ışığında çıkarılan anahtar kelimeler Tripadvisor seyahat sitesinde Kapalıçarşı ile ilgili yorumlarda aranmış ve çıkan yorumlar içerik analizine tabi tutulmuştur.

Çalışmada Ahilik kavramı açıklanarak, bu konuda yapılan çalışmalar literatür taraması bölümünde özetlenmiştir. Elde edilen veriler doğrultusunda ahilik ilkelerine sahiplik durumu bulgular kısmında ele alınmıştır. Son bölümde çalışmanın sonuçları ifade edilerek, araştırmacı ve uygulayıcılara yönelik öneriler geliştirilmiştir.

\section{YAZIN İNCELEMESİ}

Ahilik konusunda çok çeşitli disiplinlerden farklı çalışmaların yapıldığı görülmüştür. Meslek ahlakına yönelik çalışmalardan Arslan (2010) Ülgener'in meslek ahlakı ve ahiliğe ilişkin görüşlerini incelemiştir. Ahiliğin tasavvuf kültürüne yönelmesi neticesinde gözü kapalı teslimiyet, batini etkinin ortaya çıması vb. nedenlerle disiplinli çalışma prensibinin gerilediği ve böylece meslek ahlakı ve ahilik anlayışında olumsuz değişimler meydana geldiği bulgulamıştır. Yine Aslan (2013) ahilik anlayışına göre Türkler'de işin sadece maddi kazanç sağlamak anlamına gelmediğini, aynı zamanda ahlaki olarak gelişmeyi de içerdiğini söylemiştir. Bu anlayışta iş motivasyonu yüksek, hedefler ise dürüstlük ve mertlik değerlerine bağlıdır. Ahilikte kalite felsefesi, müşteri merkezli üretim ve her kademede gerçekleştirilecek eğitim anlayışına dayanmaktadır. Ahilik kurumu devlet ve halk arasındaki anlaşmazlıkları gidermektedir. Aydın (2015) ahiliğin Kur'an ve Sünnet temelliyle oluşturulduğu, ekonomik ve sosyal hayata rehberlik ettiği, ahilerin dini ve ahlaki eğitim alarak, işinde ahlaki değerleri benimsediklerini tespit etmiştir. Aytekin ve Bayramoğlu (2015) ahiliğin iktisat sosyolojisi anlamında önemli olduğunu belirtmişlerdir. Yazarlara göre, Ahilik anlayışı ekonomi-ahlak ilişkisini çok iyi bir şekilde ortaya koymuştur. Ahilik uygulamaları günümüze uyarlanarak, konjonktürel ekonomik 
dalgalanmaların olumsuz sonuçlarını bertaraf etmek için kullanılabileceği belirtilmiştir. Cevherli, Cevherli ve Çakmaktaş (2017) ahiliğin iş ahlakına dair ilkelerini ve ekonomik hayata katkılarını incelemişlerdir. Ahilik teşkilatı orta sandığı, yaşam boyu ücretsiz eğitim, adil gelir dağılımı uygulamaları ile hem ülke ekonomisine katkı sağlamış, hem de toplumsal bir sosyal adaleti sağlama konusunda etkili olduğu tespit edilmiştir. Kantarcı (2014) çalışmasında sosyal sorumluluk ve toplam kalite yönetimi uygulamalarının ahilik felsefesi ile karşılaştırmıştır. Çalışmanın sonucunda, ahiliğin akıl-ahlak temelli çalışma sisteminin, kaliteli ürünler üretmeyi sağlayan, sorumluluk bilincinin yüksek olması nedeniyle dayanışmaya, birlik ve beraberliğe ulaşmayı amaçlayan ve müşterileri velinimet olarak gören bir sistem olduğu ifade edilmiştir. Bu yönleriyle modern anlamda toplam kalite yönetimi uygulamalarıyla benzerlik gösterdiği tespit edilmiştir. Ünsür (2017) ise çalışmasında, ahilik sistemini iş ahlakı boyutuyla incelemiştir. Çalışma sonucunda ahilik sisteminin çalışma hayatını düzenlemek için, yönetim, ahlak eğitimi, kalite ve davranış konusunda önemli bir model olacağı belirtilmiştir. Öztürk (2015) çalışmasında ahilik teşkilatını günümüz ekonomisi, çalışma hayatı ve iş ahlakı açısından değerlendirmiştir. Çalışma sonucunda ahilik anlayışının işbölümü, üretim anlayışı, dayanışma, standartlaşma konularında örnek bir model olduğu, ahlaklı bireylerin yetiştirilmesi ve çalıştırılması için gerekli olduğu vurgulanmıştır.

Ahilikle ilgili uygulamaları konu alan çalışmalardan Akman (2006) Balıkesir yöresinde ahilikle ilgili gerçekleşen uygulamaları incelemiştir. Çalışma sonucunda Balıkesir yöresinde bazı tören ve uygulamaların hale devam ettiği ve sosyal hayatı birleştirici ve düzenleyici rol oynadığı ifade edilmiştir. Aydın (2016) küreselleşme ve neo-liberal uygulamalarının toplumsal anlamda açmış olduğu sorunların çözümü için insanı merkeze alan, eşitliği, barışı ve huzuru sağlayan ahilik sisteminin uygulanması gerekliliğini ifade etmiştir. Bosnalı (2004) çalışmasında ahiliğin üretim ve tüketim mekanizmasındaki yerini ortaya koyarak, ahilik değerlerinin çalışanlara aktarılması, insanı merkeze alan ve ilişkileri önemseyen bir yönetim şeklinin işletmelerce ele alınması gerektiğini belirtmiştir.

İşletmelerin ahilik değerlerine sahiplik düzeyiyle ilgili çalışmalardan Cihangir ve Karakaya (2016) ahilik kültürünün etkisini Konya Bedesten çarşısını ziyaret eden turistlerin algısına göre belirlemiştir. Çalışma sonucunda ahilik kültürünü benimseyen ve bu yönde hareket eden esnafın ziyaretçiler tarafından kabul edildiği belirtilmiştir. Zorlu, Merdan ve Ege (2012) ise çalışmasında ahilik kültürünün işletmeler tarafından bilinirlik durumunu tespit etmeyi amaçlamıştır. Çalışma sonucunda ahilik kültürünün yeterince bilinmediği ve ahilik uygulamalarının işletmeler tarafından benimsenmediğini tespit edilmiştir. Akça, (2003) fütüvvet anlayışıyla doğan fakat Türk topraklarında Türklüğün özellikleriyle sentezlenen ahilik anlayışının Türk Milletinin dini, ahlaki, iktisadi, siyasi ve sosyal hayatına yön verdiği ifade etmiştir. Ahilik teşkilatının esnaf ve sanatkârların iş ve sosyal hayatına ilişkin tutum ve davranışlarına yol gösterdiği, sosyal çevreye, genel ahlaka, sosyal dayanışmaya ve işe karşı tutumları olumlu yönde etkilerinin günümüzde de görüldüğünü belirtmiştir. Aslanderen ve Yeşil (2016) ahilik değerlerinin günümüz esnaf ve sanatkârları tarafından tam olarak yaşatılmadığını ifade etmiştir. Bosnalı (2004) çalışmasında ahiliğin üretim ve tüketim mekanizmasındaki yerini ortaya koyarak, ahilik değerlerinin çalışanlara aktarılması, insanı merkeze alan ve ilişkileri önemseyen bir yönetim şeklinin işletmelerce ele alınması gerektiğini belirtmiştir. Erbaşı, Büyükipekçi ve Bakanlar (2010) çalışmasında ahiliğin yardımlaşma, dayanışma ve birliktelik anlayışının günümüz ekonomik yapısına uyarlanmasının Türk Dünyası ülkeleri arasında iş ahlakı, tüketici odaklılık ve kalite konusunda rekabet edebilir bir yapıya kavuşmasını sağlayacağını belirtmişlerdir.

Ahilik ile toplam kalite yönetimi konusundaki çalışmalardan Çelen (2014) toplam kalite yönetimi ve ahiliği karşılaştırmıştır. Çalışma sonucunda ahilik uygulamalarının toplam kalite yönetimi ile birçok noktada örtüştüğü ve ahiliğin toplam kalite yönetimi uygulamalarının çekirdeğini 
oluşturduğu belirtilmiştir. Kantarcı (2014) çalışmasında sosyal sorumluluk ve toplam kalite yönetimi uygulamalarının ahilik felsefesi ile karşılaştırmıştır. Çalışmanın sonucunda, ahiliğin akıl-ahlak temelli çalışma sisteminin, kaliteli ürünler üretmeyi sağlayan, sorumluluk bilincinin yüksek olması nedeniyle dayanışmaya, birlik ve beraberliğe ulaşmayı amaçlayan ve müşterileri velinimet olarak gören bir sistem olduğu ifade edilmiştir. Bu yönleriyle modern anlamda toplam kalite yönetimi uygulamalarıyla benzerlik gösterdiği tespit edilmiştir. Uğurlu, Aymankuy ve Ar (2015) ise çalışmalarında turizmde toplam kalite yönetimi ve ahilik ilişkisini incelemişlerdir. Çalışma sonucunda, turizm işletmelerinin toplam kalite yönetimi felsefesindeki "çalışan ve müşteri memnuniyeti", "üretim ve hizmet standartları", "iş etiği ve ahlâkı" gibi konuların Ahilik felsefesi ile benzediği ifade edilmiştir.

Ahiliğin örgüt yönetimi ile ilişkisini inceleyen çalışmalardan Cora (2017) ahilik teşkilatının orta sandığı uygulamasının esnaf ve sanatkârların finansman problemini büyük ölçüde çözdügünü ifade etmiştir. Erbaşı (2012) ise, yönetim fonksiyonlarının ahilik teşkilatındaki uygulamalarını incelemişlerdir. Çalışma sonucunda planlama, örgütleme, yöneltme, koordinasyon ve denetim fonksiyonlarının ahilik teşkilatında da kullanıldığı vurgulanmıştır.

Ahiliğin sosyo-kültürel etkilerine yönelik çalışmada Durak ve Yücel (2010) ahilik felsefesinin günümüz toplam kalite yönetimi, müşteri memnuniyeti, çalışma ve çevre standartları, iş ahlakı konularıyla paralellik gösterdiğini ifade etmişlerdir. Mahiroğulları (2008) çalışmasında ahiliğin sosyo-ekonomik etkilerini incelemiştir. Çalışma sonucunda ahiliğin ahlak ve narh yaklaşımının kanaat sahibi olmayı, paylaşmayı öne çıkararak haksız kazancı ve aşırı zenginleşmeyi önlediği ifade edilmiştir. Ayrıca gelir dağılımının dengeli bir şekilde paylaşılmasında da etkili olduğu belirtilmiştir.

Ahiliğin mesleki eğitim ile ilişkisine yönelik yapılan çalışmada Akgündüz (2014) ahiliğin kuruluş aşamasından itibaren geçirdiği evreleri açıklayarak, mesleki eğitim yönünü ve ticari hayatta kardeşliğin yerleştirilmesi için gerçekleştirilen uygulamaları açıklamıştır. Aras (2012) ise ortaklık ilişkilerinde ahiliğin temellerinin nasıl kullanılabileceğini açıklamıştır. Çalışma sonucunda Ahilik teşkilatının benimsemiş olduğu temel değerlerin ve iş ahlakı uygulamalarının dikkate alınması ortaklar arasında değer odaklı bir ilişkinin kurulmasını sağlayarak, işletmelerin kurumsallaşma problemlerine çözüm olacağı vurgulanmıştır.

Ahilikle örneklik değeri, örtülü bilgi, destinasyon çekiciliği, pazarlama karması, psikolojik sermaye, psikolojik sorunlar, kooperatifçilik, kırsal kalkınma, tüketicinin korunmasına, esnaf birliklerinin tekelleşmesi ve sosyo-ekonomik etkilerine yönelik çalışmaların sonuçları da aşağıda özetlenmiştir.

Arslan (2015) ahilikte "insanlararası ilişkileri düzenlediği; meslek edindirme, üretim, satış, pazarlama, tüketim, isçi işveren ilişkileri, sosyal güvenlik sistemi, adil gelir dağılımı dengesi, iç ve dış güvenlik gibi alanlarda düzenlemeler yapıldığı ve başarı ile uygulandığını tespit etmiştir. Doğan (2011) çalışmasında örtülü bilginin esnaf ve sanatkarlar arasındaki gelişimi ve Ahilik ilkeleri ile ilişkisini incelemiştir. Çalışma sonucunda modern yönetim teknikleri ile Ahilik ilkelerinin benzerlik gösterdiği, bu yüzden işletme yönetiminde ahilik ilkelerinin benimsenmesinin fayda sağlayacağı sonucuna ulaşmıştır. Genç, Şengül ve Türkay (2016) çalışmalarında bir ahilik ritüeli olan "Mudurnu esnaf Duasının" destinasyon çekim unsuru olarak kullanıp kullanılmayacağını incelemiştir. Çalışma sonucunda esnaf duası geleneğinin insanlar arasında empati duygusunu desteklediği ve ilçeye özgü olan geleneğin değerli bir çekicilik unsuru olduğu ve tanıtım çalışmalarında kullanılması gerektiği belirtmiştir. Erbaşı ve Ersöz (2011) çalışmalarında ahilik ile pazarlama karması 4C'nin ilişkisini incelemiştir. Çalışma sonucunda "müşteri değeri unsurunun müşteri velinimetimizdir", "malın müşteriye maliyeti unsurunun, denetsel fiyat", "müşteriye uygunluk unsurunun, müşterinin ürüne kolay ulaşımı" 
ve "müşteri ile iletişim unsurunun, pazarla etkileşim" şeklinde ahilik anlayışının içinde yer aldığ 1 tespit edilmiştir. Kara ve Aydoğan (2017) çalışmalarında psikolojik sermaye unsurlarının ahilik teşkilatı felsefesinde bulunup bulunmadığını araştırmıştır. Çalışma sonucunda önemli benzerlikler tespit edilmiştir. Ahilik teşkilatının psikolojik sermayenin gelişmesinde günümüz işletmeleri için rehber bir kaynak olacağ ifade edilmiştir. Kavi (2015) çalışmasında iş yaşamındaki psikoloji sorunların çözümlerini ahilik teşkilatı değerleri içerisinde bulmaya çalışmıştır. Çalışma sonucunda, ahilik değerlerinin uygulanmasıyla, ahlak ve insani değerlerin kaybolduğu toplumsal yaşamda doğruluk, dürüstlük, ahlak ve kalite kavramlarının gerçek manalarının anlaşılacağı ve iş yaşamının da bu süreçten olumlu bir şekilde etkileneceği vurgulanmıştır. Serinikli (2017) kooperatifçilik ve ahi birliklerini karşılaştırmıştır. Çalışma sonucunda ahi birliklerinin karşılıklı yardım ve dayanışma, eşit kazanç, üyelerinin eğitimi, kaliteli ve ucuz mal üretimi, aracısız ürün pazarlama gibi özellikleriyle kooperatifçiliğe benzediği sonucuna ulaşılmıştır. Taslacı, Sarı ve Uysal (2016) çalışmalarında sürdürülebilir kırsal kalkınma için ahilik temelli bir model önerisinde bulunmuştur. Çalışma sonucunda, köylülerin, kamu görevlilerinin ve akademisyenlerin gönüllü şekilde oluşturdukları kurullarla kalkınma planları ahilik prensiplerini de içine alacak şekilde modellenmiştir. Gündüz, Kaya ve Aydemir (2012) çalışmalarında ahilikte tüketicilerin korunmasına yönelik uygulamalar ile günümüz uygulamalarını karşılaştırmıştır. Çalışma sonucunda Ahilik teşkilatının günümüzde tüketiciyi korumakla yükümlü kuruluşların görevlerini üstlendiği ifade edilmiştir. Ahilik teşkilatının tüketiciyi korumak için gerçekleştirdiği uygulamalar şu şekildedir. "Malların fiyatlarının uygun şekilde tespit edilmesi, imalat hatası olan ve normal dayanıklılık süresinden önce yıpranan malların yerine yenisinin verilmesi, yurt içinde üretilen veya ithal edilen malların sağlamlığı, kalitesi ve sağlığa zararlı olup olmadığının kontrol edilmesi ve böylece müşteri memnuniyetini merkez alan bir anlayış geliştirilmesidir. Bunu sağlamak, üretimde kaliteyi arttırmak, arz ve talep dengesini oluşturmak ve kaynak israfını önlemek için her alanda, günümüz modern dünyasının uygulamalarıyla özdeş sayılabilecek standartlar düzenlenmiş ve buna uymayanlar cezalandırılmıştır." Bayram (2012) ise çalışmasında ahilik teşkilatı ve esnaf loncalarının Osmanlı'nın son döneminde tekelleşmeye gittiği bu nedenle fiyatların yükselmesine neden olduğunu ifade etmiştir. Bu sebeple esnaf birliklerinin ortadan kalktığı sonucuna ulaşılmıştır. Çeker (2017) ahiliğin ahlaki ve sosyo-ekonomik yapıya etkilerini incelemiştir. Ahiliğin kapitalizm ve liberalizmin olumsuz yönlerini giderebilecek bir unsur olduğunu vurgulamıştır.

\section{Ahilik İlkeleri}

Akgül (2017) çalışmasında ahilik ilkelerini 4 boyut altında incelemiştir. Bunlar kaliteye önem verme, sosyal güvenlik ve yardımlaşma, müşteriyi önemseme ve rekabeti algılama boyutlarıdır. Ahilerin ürünlerini kaliteli bir şekilde üretmesi, müşterileriyle iyi bir iletişim kurmaları, rekabette bile esnaf kardeşine haksızlık yapmaması ve yardımlaşması gerektiği vurgulanmıştır. Ahilik ilkelerine yönelik çalışmalardan Akgül (2017) esnafların sosyal sorumluluk ilkelerine uygun davrandıklarını bulgulamıştır. Esnaf arkadaşa yardım, müşteri yönlendirmede ve rekabet konusunda esnafların kararsız kaldıkları tespit etmiştir. Ayrıca ahilik sisteminin günümüz uygulamalarıyla bütünleştirilmesi gerektiği vurgulanmıştır.

Karagül ve Masca (2017) çalışmasında ahilik sistemini ve kapitalist sistemi kıyaslamıştır. Karagül ve Masca (2017)'de benzer şekilde ahiliğin ilkelerini sınıflandırmıştır. Yazarlara göre ahilik ilkeleri, kanaatkârlık, yardımlaşma, iş ahlakı, ürün kalitesi, usta çırak ilişkisi, iş bölümü ve iç denetim sistemi boyutlarıdır. Çalışma sonucunda ahilik sisteminin kapitalist sisteme göre insanlığın refahı ve barışı, çevreye karşı duyarlılığı konularında önemli ilkeleri benimsediği belirtilmiştir. 
Yeşil ve Aslanderen (2017) ahilerin sahip olması gerektiği ilkeleri maddeler halinde sınıflamışlardır. Çalışma da ahilerin mesleğin gerekli standartlarına uymaları, insanlarla karşılıklı olumlu ilişkiler geliştirmeleri, mesleki gelişim ve eğitim gayret göstermeleri ve müşterileri aldatmaya ve kandırmaya yönelik faaliyetlerden uzak durmaları gerektiği vurgulanmıştır.

Soysal ve Tan (2013) çalışmalarında ahilik ilkelerinin günümüz işletmelerinde ne ölçüde uygulandığını belirlemeyi amaçlamışlardır. Soysal ve Tan (2013) ise ahilik ilkelerini şu şekilde açıklamıştır. Ahilik ilkeleri; çalışan personelle, müşterilerle ve komşu esnaflarla ilişkiler, çalışanların ve yöneticilerin genel görünümü, mesleki gelişim ve çevre boyutlarında ifade edilmiştir. Çalışma sonucunda işletmelerin çalışanları, müşterileri ve diğer işletmelerle olumlu ilişkiler yürüttükleri fakat mesleki gelişim ve çevre konusunda gerekli hassasiyeti göstermedikleri belirtilmiştir.

Soysal (2013) çalışmasında ahilik ilkelerinin işletmelerin başarısındaki önemiyle ilgili bir değerlendirme yapmıştır. Çalışma sonucunda, günümüz işletmelerinin piyasada rekabet edebilmesi ve müşterileri memnuniyetini sağlayabilmeleri için ahilik geleneğinde de olan "etik ilke ve yöntemlere" başvurdukları ifade edilmiştir. Ayrıca ahilik ilkelerinin sosyal barışı sağlama, güçlünün zayıfı ezmesi, sömürüyü, ahlaksızlığı, düşmanlığı, kini ve nefreti engelleme işlevi olduğu vurgulanmıştır.

\section{Kapalı Çarşı ve Turizm}

Fatih Sultan Mehmet tarafından 1461 yılında yaptırılmaya başlayan Kapalıçarşı Dünya'nın en eski ve en önemli alışveriş merkezlerinden biridir. Kapalıçarşı, $45.000 \mathrm{~m}^{2}$ bir alan üstünde 3.600 dükkânın bulunduğu, halı, çanta, tekstil ürünleri, altın ve mücevherat, antika çiniler vb. birçok ürünün sunulduğu, yerli ve yabancı turistlerin ziyaret ettiği bir bölgedir (www.kulturportali.gov.tr).

İstanbullu Dinçer ve Kanay (2017) yılında gerçekleştirdikleri çalışmada Kapalıçarşı'nın özellikle alışveriş turizmi açısından ekonomik ve sosyal etkilerini değerlendirmişlerdir. Bu değerlendirmede İstanbul'un en önemli destinasyonlarından biri olarak Kapalıçarşı'nın büyük bir turistik çekiciliğe sahip olduğunu, fakat yeterli düzeyde tanıtımının yapılmadığını ve kültürel olarak bir yozlaşma içerisinde olduğunu belirtmişlerdir. Bir başka çalışmada Kapalıçarşı esnafının turizm ile ilgili algıları incelenmiştir. Çalışma sonucunda Kapalıçarşı esnafının turizm konusunda yeterli bilgiye sahip olmadığı ifade edilmiştir. Ayrıca Kapalıçarşı'nın geleceğinin turizmle ilişkilendirilmesiyle mümkün olduğu belirtilmiştir (Zengin ve Şengel, 2014). Zengin ve Şengel (2014) esnafın genel anlamda eğitiminin yeterli olmamasından dolayı turizmle ilgili bilgi ve algisında da problemler olduğu, esnafların yerli turist kavramını bilmedikleri, turist denildiğinde yabancı bir dil konuşan ve farklı toplumdan kişileri algıladıkları vurgulamışlardır.

Kapalıçarşı'nın; tarihi yapısı, birçok ürünü bir arada bulundurması, tarihi yarımadada bulunması ve İstanbul gibi bir destinasyonda yer alması turizm açısından büyük bir değer olduğunu ortaya koymaktadır. Yapılan çalışmalarda da özellikle alışveriş turizmi açısından değerlendirilmesi ve esnaf ve sanatkârların turizm konusundaki farkındalığının arttırılması gerektiği ifade edilmiştir.

\section{YÖNTEM}

Araştırmanın amacı İstanbul Kapalıçarşı esnaf ve sanatkârlarının ahilik ilkelerine sahiplik düzeylerinin belirlenmesidir. Araştırmanın amacına ulaşabilmek için nitel araştırma 
yaklaşımından faydalanılmıştır. Böylece Kapalıçarşı'yı ziyaret eden yerli turistlerin, esnaf ve sanatkârlar hakkındaki görüşlerinin derinlemesine analiz edilebileceği ve ahilik ilkelerine sahiplik düzeylerinin belirlenebileceği düşünülmektedir. Çalışmada veri toplanması amacıyla TripAdvisor seyahat sitesindeki İstanbul Kapalıçarşı'sına ait Türkçe olarak yorumlanan toplam 727 adet yorum incelenmiştir. Bu yorumlar içerisinde "esnaf, sanatkâr, satıcı" anahtar kelimeleri aranmış ve söz konusu kelimeleri içeren 47 yorumdan elde edilen veriler içerik analizi yöntemiyle incelenmiştir.

\section{BULGULAR}

İstanbul Kapalıçarşı esnaf ve sanatkârlarıyla ilgili yerli turistlerin TripAdvisor seyahat sitesinde yapmış oldukları yorumların içerik analizi sonucunda 1. Esnafın turistlerle iletişim tarzı; 2. Esnaf çeşitliliği 3.Esnafların mesleki gelişimi temaları ortaya çıkarılmıştır. Temalar, kodlar ve yorum sayıları Tablo 1'de sunulmuştur.

Tablo 1. Yerli Turistlerin Esnaf ve Sanatkârlarla İlgili Yorumları

\begin{tabular}{llc}
\hline Temalar & \multicolumn{1}{c}{ Kodlar } & Yorum Sayısı \\
\hline 1.EsnaflarınTuristlerle & 1.1. Israrcı Olma & 6 \\
İletişim Tarzı & 1.2. Güler yüzlülük ve İlgili Olma & 7 \\
& 1.3. Kabalık ve Saygısızlık & 6 \\
& 1.4. Ayrımcılık & 10 \\
& 1.5. Pazarlık & 6 \\
& 1.6. Turisti Aldatıcı Davranışlar & 4 \\
\hline 2.Esnaf Çeşitliliği & 2.1.Farklı Meslek Grupları & 2 \\
& 2.2.Farklı Kültür ve Diller & 3 \\
\hline 3. Esnafların Mesleki & 3.1. Eğitim & 2 \\
Gelişimi & 3.2. Kendini geliştirme & 1 \\
\hline
\end{tabular}

\section{Esnafların Turistlerle İletişim Tarzı}

Yorumlar incelendiğinde İstanbul Kapalıçarşı'yı ziyaret eden yerli turistlerin, esnafların iletişim tarzıyla ilgili olumlu ve olumsuz bazı görüşlerinin olduğu tespit edilmiştir. İçerik analizi sonucunda ısrarcı olma, güler yüzlülük ve ilgili olma, kabalık ve saygısızlık, ayrımcılık, pazarlık ve turisti aldatıcı davranışlar kodları belirlenmiştir.

Yorumlardan esnaf ve sanatkârların dükkân kapılarının önünde ısrarcı bir şekilde turistleri içeri çekmek istedikleri, turistlerin vitrinleri rahat bir şekilde izleyemedikleri ve özgürce gezemedikleri sonucuna ulaşılmıştır. Aşağıdaki alıntılarda esnaf ve sanatkârların ısrarcı olmalarıla ilgili ifadelere yer verilmiştir.

"Eskiden Kapalıçarşı çok daha güzeldi. Sanırım ekonomik nedenlerden dolayı artık daha boş. Turistleri sevmeme rağmen Arap yarımadasından gelenlerden haz almıyorum. Araplar da buralar mesken tutmuşlar. Esnaf bildiğiniz gibi kapı önlerinde sizi içeri çekip bir şeyler satmaya çalışıyorlar. Boş boş gezen çok insan var. Ama eski tadı hiç kalmamış."

"Alışveriş yapmak için gittiğimde 2 arkadaşımla birlikte inanın utandım. Neden bă̆ırıyorsunuz? Vitrinlere bakmak istiyorsunuz hemen yanınızda bir eleman beliriyor, bakmaktan vazgeçiyoruz. Yapmayın arkadaşlar yerli yabancı alı̧̧erişe çıkmış insanlar bırakın rahatça gezsinler zaten beğendikleri ürünleri dönüp dolaşıp alırlar. Saygilı esnaf istiyoruz..!" 
“Ortadoğu çarsılarını andırsa da tabi ki de bize özgü şeyler de var fakat halılar ve süs eşyaları pahalı bir de esnaf sürekli Buyrun Buyrun diyerek biraz rahatsizlık verse de insan kendini alamadan gezmeye devam ediyor. Aslında buradan güvenerek altın ve perlanta alabilirsiniz"

"Özellikle çocukların tarihi dokuları görmesi için güzel bir yer. Bazı yerlerde esnaf fazla ilgi gösterse de rahat gezilebilecek yer."

“İstanbul'un güzelliği ayrı bir kültür renkli keyif alacağınız seyahatinize mutlaka eklemeniz gerekli güzel bir mekân İstanbul'un olmazsa olmazı. Kapalı Çarşı günün her saatinde hareketli ve kalabalıktır. Esnaf, ziyaretçileri ısrarlı olarak kendi mağazasına çă̆ırır. Çarşı girişinde gelişen konforlu, büyük mağazalar Türkiye'de elde imal edilen ve ihracatı yapılan hemen hemen bütün eşyaları satışa sunmaktadır. El halıları ve mücevherat geleneksel Türk sanatının en güzel örnekleridir. Bunlar kalite ve orijin belgeleri ile satıllr ve dünyanın her tarafina garantili gönderme yapılır. Halı ve mücevheratın yanında meşhur Türk işi gümüşten yapılmış eserler, bakır, bronz hediyelik ve dekoratif eşya, seramik, oniks ve deriden mamul, üstün kaliteli, Türkiye hatıralarn zengin bir koleksiyon"

“Çok güzel tarihi bir mekân ama esnaf fiyatları 2-3 kat yukarı çekiyor. Her şeyin fiyatına ulaşılabilen bir ortamda insanları saf yerine konulması tiksinti veriyor. O güzel ortamın tadını kaçırıyor. Esnaf bir şeylere bakarken çok yapışıyor, rahat edemiyorsunuz. Giriş ücretsiz, hafta sonları kalabalık."

Esnaf ve sanatkârlarm güler yüzlü ve ilgili olduklarına yönelik yorumlar incelendiğinde iki farkl görüş tespit edilmiştir. Illk görüş esnafların güler yüzlü ve ilgili oldukları, ikinci görüş ise esnafların misafirperver ve güler yüzlü olmadıklarına yöneliktir. Aşă̆ıldaki alıntılarda yorum yapanların (ya da müşterilerin) bu konuyla ilgili ifadelerine yer verilmiştir.

"Altınlar çarşısı modeller harika olmuş ellerine sağlık. Esnaf güler yüzlü ne ararsan var. Her sokakta caddesinde alışveriş mümkün"; "her şeyiyle tarih kokan Kapalıçarşı'yı bu sefer gezmek amaçlı dolaştık. Tabi ki en çok Kuyumcular ve Halıcılar dikkatimizi çekti. Esnaf son derece ilgili ve güler yüzlü olarak hizmet veriyor. Burada hep huzur buldum. Şimdi mısır çarşı sına geçeceğiz. Kahvaltılık almak için" ve baharat kokusu ve esnaf muhabbeti için burası tek geçilir. Kapalı çarşı Osmanlı ve Yaşantısını Hala devam ettiren bir yer."

“İstanbul'un gezmesi en rahatsız edici mekânıdır. Bir zamanların güler yüzlü, misafirperver 'esnaf' algısının olmadığı, turistlerin ve 'cepçilerin' cirit attı̆̆ı 'kadim pazar'. Uzun zaman önce keyifle gezdiğimiz ve alışveriş ettiğimiz hatırlıyorum. Fakat bugünlerde elinizde büyükçe bir fotoğraf makinesi gördüklerinde sizi dükkânlarının önünden kovuyorlar. İçerden alı̧̧eriş etmek zor, gereksiz pahalı. Tarihi bir yapı olması nedeniyle tabi ki büyüleyici. Gezin derim, ama eski tadı yok artık Kapalı Çarsının."

“Tarihi bir mekân. İstanbul'a gelip de kesinlikle görülmesi gereken bir yer. Esnaf güzel ilgi ve alaka gösteriyor. Aradığınız her şeyi bulabilirsiniz bence zaten bir günde imkânı yok gezemezsiniz İstanbul'da 3 yıl içinde defalarca gitmeme rağmen hala çıkış kapılarını özellikle Mahmutpaşa'ya açılan kapıyı bulamadım sanki biraz karmaşık".

“Kapalı Çarşı'nın dünü ve bugününü karşılaştırdığım zaman çocukluk dönemi Çarşısı benim için daha güzeldi. O dönemde yani 1960'larda Kapalı Çarşı içinde her şey satılırdı. Aklımda kalan oyuncak mağazaları bile vardı ve alış verişin büyük bir kısmı Türk müşteriler için ayrılmıştı. İçindeki Bedestende açık arttırmalar yapılırd. Daha sonraları turizmin gelişmesi ile bazı iş kolları ne yazık ki yerlerini halı, kutum ve diğer ticari mağazalara bıraktılar. Bugün gelen turistlerin uğrak yeri. Sabah 10 gibi gitmenizi öneririm. Kalabalı̆̆ın az olduğu bu saatlerde çarşıdan daha çok zeok alabilirsiniz. Mutlaka ara sokaklara, hanlara girip geziniz. Esnaf yardımcıdır ve hiç çekinmeden fiyat sorabilirsiniz. Yorulursanız Şark kahvesine uğrayıp bu tarihi mekânda çayınızı kahvenizi içmeyi unutmayın." 
"İstanbul'un en eski tarihi iste çarsıya girdiğinizde otantik havası müthiş bir ambiyansı var alışveriş yapmamak imkânsız gibi bir şey cidden her mağazası ayrı güzel bazı esnaf suratsız ona da yapacak bir şey yok"

Esnaf ve sanatkârların kabalık ve saygısızlık yaptıklarına yönelik yorumlar incelendiğinde, esnafların nezaketsiz, kaba ve sert bir şekilde davrandikları, arsız ve açgözlü oldukları, saygısız ve sabırsız bir şekilde davrandıkları tespit edilmiştir. Aşağıdaki alıntılarda ilgili ifadeler sunulmuştur.

"İstanbul' un görülmesi gereken yerlerden birisi ama kapalı çarşı esnafi kibarlıktan ve nezaketten çok uzak ve çok kaba hiç sevmediğim esnaf tipleri. Aslında dünyanın ilk alışveriş kapalı alanı oraya elini kolunu sallayana dükkan açma izni vermeyeceksin oradaki esnafları eğitimden geçireceksin böyle kaba saba ve sırf turist kazıklamak için orada iş yapanlara müsaade edilmemelidir. İş̧allah en yakın zamanda yetkililer bir önlem alır bu konuda."

"Avrupa'dan gelen birisi olarak büyük çarsıdaki esnafı çok kınadım, çok sert tepkiler ve nerdeyse darbe yemeye kadar gidecekti, esnaf çok sinirli bazıları orada ekmek kazanmayı bile hak etmiyor maalesef çok soğudum kimseye tavsiye etmiyorum yurt dişi ve içi insanlarmıza kesinlikle tavsiye etmiyorum."

"İstanbul'a gelip de Kapalı Çarşı ziyaret etmemek olmaz. Bu durumda İstanbul'u tam anlamıyla ve hakkıyla görmüş ve yaşamış sayılmazsınız. İçinde otantik lokanta ve kahveleri, özgün alışveriş bedestenleri barındıran bu büyük mekan ne yazık ki arsız, aç gözlü esnafı yüzünden giderek 'yalnızlaşıyor"

"Benim gibi alış-verişten ziyade gezmek, görmek amaçlı ziyaretçi sayısı arttıkça da dükkan sahiplerinin işleri zorlaşıyor. Ama iğneyi hatta çuvaldızı kendilerine batırmalılar, önlerinden geçen herkesi 'soyulacak kaz' sanmak en hafif söylemiyle terbiyesizlik. Buna karşın rengârenk ve her çeşit ürünün yer aldığı dükkânlarıyla Kapalı Çarşı görülmesi gereken bir panayır, rüya diyarı."

"İstanbul'un incisi ve hatta Türkiye'nin incisi. Gezmekten her daim keyif aldığım bazı sulu ve saygısız esnafina rağmen altın almak gerektiğinde akla gelen ilk tarihi çarsı"

“İstanbul'un en eski çarşılarından birisi. Her kapısı adeta tarihe açılan bir lokasyon. Esnaf git gide kalitesizleşiyor. Eski hoşgörü ve eski insanların sabrı kalmış değil. Bölge turistten besleniyor. Tabi ki İstanbul'un bu han dünyanın göz bebekleri arasinda nadide bir eser"

Esnaf ve sanatkârların ayrımcılık durumlarına yönelik yorumlarda esnafların yerli turistlerle ilgilenmedikleri, ikram vb. hizmetleri yabancı turistlere yönelik sundukları ve turistleri ekmek kapısı olarak gördükleri ifade edilmiştir. Aşağıda alıntılanan ifadeler sunulmuştur.

"En son kapalı çarşıya 7 yıl önce gelmiştim. Bu geldiğimde şunu fark ettim. Bu çarşı hala çok güzel. Ancak esnaf biraz kendini geliştirmeli. Turist olmayan kişilerle neredeyse ilgilenmiyorlar."

"Hemen hemen bütün esnaf turistin ekmek kapısı olarak düşündüğü, tarihi kapalı çok büyük geniş kesinlikle tekrar tekrar gelip aktarlar hediyelik eşyaların ve benim için önemli eski Osmanl ışıklarının etrafında çarşının içinde kaybolabileceğiniz kapalı çarşı"

"Tarihi doku görmek isteyen mısır çarşısını tercih edebilir. Gelin görün ki burada tarihi dokunun yanında esnaf o kadar esnaflıktan çıkmış ki alışveriş için gitmek bir hata olur. Turist düşürmek için tutturabildiklerine satan dükkân sahipleri varken bir daha yolumu düşürmem."

"Ne yazık ki eski kapalı Çarşı'dan çok farklı yerli esnaf kalmamış Arap turiste yönelik hizmet kendinizi resmen dışlanmış hissediyorsunuz Çok üzücü yerli esnafı da bundan şikâyetçi"

"Tamamen turistlere yönelik çalışan iş yapan bir esnaf var içeride. Düşünün önünüzden Arap aile geçerken ikram tepsisini uzatıyor arkadan siz geliyorsunuz tepsi direk geri çekiliyor size de uzatılmıyor e onlarda haklı görgüsüz Araplar Hintliler vs. aldılar mi valiz valiz alıyorlar napsinlar bizi. Esnafi gerçekten berbat bir esnaf hatta esnaf değil ki başka bişey (....) ayrıca içerisi turist kaynadığı içinde ucuz falan sanmayın gayet pahalı." 
"Kapalıçarşı ziyaretim sırasında üzülerek belirtmeliyim ki özellikle çarşının iç kısmında Türkçe konuşuyorsanı hiç bir esnaf yüzünüze bakmaz sizinle ilgilenmez sizi müşteri yerine koymaz dahası var çarşıdan çıkınca \%90 -95 ihtimalle asla bir taksi çeviremezsiniz Turist olmadığınız için maalesef kendi ülkemizde turistik yerlerde durum bu sizinle paylaşmak istedim"

"Gezip görmek için güzel bir yer eski bir tarihi yapı olduğunu hissediyorsunuz fakat alışveriş için ayni şeyleri söyleyemem esnaf turiste odaklı ne koparabilirsem Modunda ."

"Suudi Arabistan'dan gelen misafir ailemiz ile ziyaret ettik. Bu muhteşem tarihi çarşıyı tam bir turist kazıklama merkezine çevirmişler maalesef. Esnaf (istisnalar kaideyi bozmaz) satış sistemini özellikle zengin Araplara yönelik oluşturmuş. Marka ürünlerin çakmalarma orijinalinden daha yüksek fiyat çekiyorlar. Misafirimiz olan Arapları uyarmamıza rağmen zapt edemedik ve bayan çantası ile cüzdan aldılar. Hem de olması gereken imitasyon fiyatının 10 katına. Ama gerçekten esnaf kendi ayağına sıkıyor. Bu güzelim çarşının yakında adı çıkacak korkarım."

"Yillardır gidiyorum ama bir şey alamıyorum her şey çok pahalı zaten esnaf yerli ziyaretçileri davet etmiyor genellikle yabancilarl davet edip ikramlarda bulunuyor"

"İstanbul da en sevdiğim yerlerden biri. Tarihi yapısı büyük bir hayranlık uyandırıyor. Fakat aynı ürünler farklı fiyatlar barındırıyor. Anlayacağını tutturabildiğine genelde turistlere hizmet anlayışı içinde olan bir esnaf topluluğu var. Bir şey almadan önce iyice gezmek iyi bir fiyat araştırması yapmak gerekiyor. Illk girilen yerden alışveriş̧ yapmak zorunda değilsiniz bu ayıp bir şey değil sadece üzerinizden o baskıyı atın genelde insanlar utandıklarından hemen ilk yerden alışveriş yapıyorlar. Gezin ve araştırın".

Esnaf ve sanatkârların pazarlık yapma durumlarına yönelik yorumlarda esnafların ürünlerle ilgili sıkı alışveriş yaptıkları, turistlerinde mutlaka pazarlık yaparak satın alması gerektiği vurgulanmıştır. Aşağıda alıntılanan ifadeler sunulmuştur.

“Günümüzün AVM'lerin atası mı bilemem ama ülkemizin gurur kaynağı olan bir yapı. Bir kapıdan girip içinde anında kaybolabilirsiniz. Insanlar ve esnaf; urun pazarlikları alım satım ve hayat devam ediyor. Kuyumcular, hediyelik eşyacılar, kilimciler, baharatçılar ve diğerleri."

"Yunanlılar zamanından gelen, Osmanlının Türkiye'ye bıraktı̆̆g bir eser. Yüzlerce ırktan esnaf inanılmaz güzel bu alışveriş merkezine bir renk, bir ahenk getirmiş. Pazarlı etmeniz gerekir ama eğer dikkatliyseniz çok uygun fiyatlara alışveriş edebilirsiniz. Bu sihirli eseri kesinlikle ziyaret edin."

"Gezildikten sonra mutlaka olumlu ayrılacağınız bir yer. Alışverişte esnaf ile pazarlık yapın. İyi eğlenceler."

"Alış veriş bahane, gezmek, görmek keyif verici. Gözünüz gönlünüz bayram etsin. Mümkünse hafta arası gitmenizi tavsiye ederim. Daha tenha oluyor, hafta sonuna nazaran. Sıkı pazarlıklar yapıp güzel alışeriş yapabilirsiniz aynı zamanda. İhtiyacınız var ise tabii. Yoksa zaten o atmosferde bulunmak insanı oldukça etkiliyor. Gümüşçüler çarşısına da girmenizi öneririm. Esnaf lokantasında yemek molası tabiki."

"Bu çarşı, dünyanın ilk AVM si olma özelliğini taşırken, içine çöreklenmiş, ticari ahlak ve koşullardan yoksun esnaf yüzünden değerini yitirmemeli. Her bir sokağını gezmeli, el sanatı ürünleri mutlaka görmelisiniz. Alı̧̧veriş yaparken mutlaka pazarlık yapın"

"Kapalı Çarşı İstanbul'un simgelerinden, turistlerin asla uğramadan dönmediği, buram buram tarih kokan, Türk kültürrüne dair birçok hediyeliğin satıldığı enfes bir çarşı. Birden çok giriş kapısı bulunan çarşı da her sokakta farklı bir deneyim yaşayacaksını. Antika eşyalardan, dokuma halılara, altın gümüşten, seramik hediyeliklere eşyalar kadar birçok farklı şey sizi bekliyor. Pazarlığa açık bir esnaf kitlesi var, o yüzden ilk duyduğunuz fiyatlar sizi korkutsa da zorlayın". 
Esnaf ve sanatkârların turisti aldatıcı davranışlarına yönelik yorumlarda esnafların turistlere alı̧̧eriş sırasında fahiş fiyatlar uyguladıkları ve kandırmaya yönelik eylemler gerçekleştirdikleri ifade edilmiştir. Aşağılda alıntılanan ifadeler sunulmuştur.

"Ticaretle uğraşan biri olarak Türk Esnaflı̆̆ının, Ahiliğin merkezi olan Kapalı Çarşının halini gördüğü̈mde içim acıdı. Sahtekârlığın en uç noktaya ulaştığı, Fahiş fiyatların tavan yaptığı, Esnaflığın bittiği, Turisti (yerli ve yabancı) kazıklama yöntemlerinin üniversitesi olduğu Muhteşem Mimarinin yok edilmek için çaba harcandığı Tarihi Eser. İçerideki esnaf görünümlü vatandaşların ne kadar tarihi eserin tüm duvarlarına çiviler çakarak sahte ürünlerle doldurduğunu görsek de Tavana boyları ermemiş. Elektrik ve telefon kablolarının çirkinliği eşliğinde Türk ve Osmanlı Mimari'sinin izlerini kendi çabasıyla korumaya çalışan Kapalı Çarşı Tamamen yok edilmeden görülmesi gereken Ama Alışveriş yapılmaması gereken başlica yerler listesindedir."

"Beyazıt Kapısı'nın iki yanında eskiden sakız satarlarmış. Alışverişe gelen kadınlar çocuklarına sakız alırmış buradan. İçeride çok konuşmasınlar, bağrış çă̆rış yapmasınlar da rahat alışveriş yapalım diye (1960'lar...) Şimdi kapının önünde imitasyon çanta satanlar var. Şimdilerde ise insanları nasıl kandıralım nasıl parasını alırı diye çalışıyorlar eski esnaf ise tam bir esnaf imiş anca turistlerin ilgisini çeken bir yer artık onlarda yavaş yavaş bunun farkına varıyorlar kolay kolay alışveriş yapmıyorlar rahat bir şekilde gezemiyor içini gezmenin bir mantığı yok benim görüşüm dışından gezseniz daha iyi"

"Suudi Arabistan'dan gelen misafir ailemiz ile ziyaret ettik. Bu muhteşem tarihi çarşıyı tam bir turist kazıklama merkezine çevirmişler maalesef. Esnaf (istisnalar kaideyi bozmaz) satı̧sistemini özellikle zengin Araplara yönelik oluşturmuş. Marka ürünlerin çakmalarnna orijinalinden daha yüksek fiyat çekiyorlar. Misafirimiz olan Arapları uyarmamıza rağmen zapt edemedik ve bayan çantası ile cüzdan aldılar. Hem de olması gereken imitasyon fiyatının 10 katına. Ama gerçekten esnaf kendi ayağına sıkıyor. Bu güzelim çarşının yakında adı çıkacak korkarım."

"İstanbul'a gelip de Kapalı Çarşı ziyaret etmemek olmaz. Bu durumda İstanbul'u tam anlamıla ve hakkıyla görmüş ve yaşamış sayılmazsınız. İçinde otantik lokanta ve kahveleri, özgün alı̧ veriş bedestenleri barındıran bu büyük mekân ne yazık ki arsız, açgözlü esnafı yüzünden giderek 'yalnızlaşıyor' benim gibi alış-verişten ziyade gezmek, görmek amaçlı ziyaretçi sayısı arttıkça da dükkân sahiplerinin işleri zorlaşıyor. Ama iğneyi hatta çuvaldızı kendilerine batırmalılar, önlerinden geçen herkesi 'soyulacak kaz' sanmak en hafif söylemiyle terbiyesizlik. Buna karşın rengâarenk ve her çeşit ürünün yer aldığı dükkânlarıyla Kapalı Çarşı görülmesi gereken bir panayır, rüya diyarı."

\section{Esnaf Çeşitliliği}

Elde edilen yorumlardan, farklı meslek grupları ve farklı kültür ve diller kodları ortaya çıkarılmıştır. Esnaflara yönelik yorumlarda Kapalıçarşı da çok farklı ve çeşitli esnaf gruplarının (baharatçılar, hasırcılar, kuyumcular) bulunduğunu ve farklı dilleri konuşan, farklı kültürden esnafların çalıştığını ifade etmişlerdir. Aşağıda alıntılanan ifadeler sunulmuştur.

"Bir şeyler almak için koskoca İstanbul'u gezmenize gerek yok ayrica içeride her istediğinizi bulabiliyorsunuz. Öğrendiğime göre çok eski zamanlarda kapalı çarsının her sokağında farklı satıcılar bulunurmuş yani söyle bir sokak komple altın satanlar bir sokakta komple baharatçllar hasırcılar vs. vs. her sokak farklıymış fakat şimdi kapalı çarsıyı gezmeye kalktı̆̆ınızda içerdi bildiğiniz kayboluyorsunuz bunun nedeni her sokakta farklı farklı esnaf dükkân açmış. O yüzden ki kapalı çarsıya girdiğinizde her seferinde kaybolursunuz".

“Burası güzel ve çok büyük bir yer ben İstanbul'da doğan birine rağmen kapalı çarşının tamamını gezemedik ama gezmek isterdim İstanbul'un tam merkezinde ve çok esnaf var". 
"Yunanlllar zamanından gelen, Osmanlının Türkiye'ye bıraktı̆̆ı bir eser. Yüzlerce ırktan esnaf inanılmaz güzel bu alışveriş merkezine bir renk, bir ahenk getirmiş. Pazarlı etmeniz gerekir ama eğer dikkatliyseniz çok uygun fiyatlara alışveriş edebilirsiniz. Bu sihirli eseri kesinlikle ziyaret edin."

"Dünyada esi benzeri bulunamaz bir çarsı. Mükemmel bir atmosfer. Her turlu esnaf var. Her dili konuşuyorlar ve altın, hali, antika da dünyada en iyi yer. Herkesin gitmesi gereken tarihi mirasımı."

“Ne yazık ki eski kapalı Çarşı'dan çok farklı yerli esnaf kalmamış Arap turiste yönelik hizmet kendinizi resmen dışlanmış hissediyorsunuz Çok üzücü yerli esnafı da bundan şikâyetçi".

\section{Esnafların Mesleki Gelişimi}

Elde edilen yorumlardan eğitim ve kendini geliştirme kodları ortaya çıkarılmıştır. Yorumlarda esnafların kendilerini geliştirmeleri ve eğitim almaları gerektiği ifade edilmiştir. Ayrıca tarihi süreçte esnaf odalarının, çırakların eğitim gördüğü bir ticaret merkezi olduğu vurgulanmıştır. Aşağıda alıntılanan ifadeler sunulmuştur.

"En son kapalı çarşıya 7 yıl önce gelmiştim. Bu geldiğimde şunu fark ettim. Bu çarşı hala çok güzel. Ancak esnaf biraz kendini geliştirmeli. Turist olmayan kişilerle neredeyse ilgilenmiyorlar."

"İstanbul un görülmesi gereken yerlerden birisi ama kapalı çarşı esnafı kibarlıktan ve nezaketten çok uzak ve çok kaba hiç sevmediğim esnaf tipleri. Aslında dünyanın ilk alış veriş kapalı alanı oraya elini kolunu sallayana dükkân açma izni vermeyeceksin oradaki esnafları eğitimden geçireceksin böyle kaba saba ve sırf turist kazıklamak için orada iş yapanlara müsaade edilmemelidir. İnşallah en yakın zamanda yetkililer bir önlem alır bu konuda."

"Yüzyıllardır İstanbul'un cazibe merkezi, el sanatları, kuyumculuk, mücevher konusunda hem ticaret hem de eğitim merkezi olmuş bir kompleks. Tüm dünyadan en nadide mücevher, antikalar, saatler, objeler bulacağınız Cevahir Bedesten en favori bölümü olsa da Nuru Osmaniye Kapısından girerek baharat kokuları altında ana caddesinden yürümek her zaman çok etkileyici.

İstanbul'a yolu düşen her gezginin merakla ziyaret ettiği Kapalı Çarşı her geleni memnun etmesini biliyor. Yeni açılan Nusret Restaurant yanında her zaman lezzetli Türk yemeklerini tadacağını Havuzlu Restaurantı ve eşsiz dekorasyonu ile çok beğgndiğim Çinili Kahvesine uğramadan geçmeyin derim. Geçmiş zamanlarda esnaf odalarının olduğu, çıraklara eğitimlerin verildiği bir ticaret merkezi olma özelliğini hala sürdüren Kapalıçarşı'nın arka sokaklarında hala yoğun üretim ve ticaret trafiği devam ediyor. Pazar günleri kapalı, cumartesileri hayli kalabalık olsa da mistik havası her geleni mutlu ediyor".

\section{TARTIŞMA, SONUÇ ve ÖNERILLER}

Esnaf ve sanatkârların Ahilik ilkelerine sahip olması, onların müşterilerine değer veren, aldatmayan ve işini doğru yapan kişiler olduğu anlamına gelmektedir. Özellikler Turistlerle sürekli iletişim halinde olan Kapalıçarşı Esnaf ve Sanatkârları bu ilkelere sahip olması gerekmektedir. Gerçekten Ahilik ilkelerine sahip olup olmadıklarının belirlenmesi önemli bir konudur. Bu yüzden yapılan araştırmada Kapalıçarşı esnafı ve sanatkârlarının ahilik değerlerine sahip olup olmadıkları tespit edilmeye çalışılmıştır. Çalışmada Tripadvisor seyahat sitesinden elde edilen yorumlar içerik analizi ile incelenmiş, temalar ve kodlar oluşturulmuştur.

Çalışma sonucunda, esnafın turistlerle iletişim tarzı; esnaf çeşitliliği ve esnafların mesleki gelişimi temaları ortaya çıkarılmıştır. Yorumlar incelendiğinde İstanbul Kapalıçarşı' yı ziyaret eden yerli turistlerin esnafların iletişim tarzıyla ilgili olumsuz yorumlar açıklanmış, fakat olumlu yorumlara yer verilmemiştir. Yerli turistler esnafların ısrarcı davranışlarından rahatsız olduklarını, zorla 
dükkânlarına sokmak istediklerini ve alışverişlerini rahat bir şekilde yapmalarını engellediklerini ifade etmişlerdir.

Kapalıçarşı esnaf ve sanatkârlarının yerli turistlere karşı kaba ve saygısız davranışlarının olduğu tespit edilmiştir. Esnaf ve sanatkârların yerli turist ve yabancı turist arasında ayrımcılık yaptıkları yerli turistlerle daha az ilgilendikleri ve onlara daha az hizmet sundukları ifade edilmiştir. Esnafların turistleri aldatıcı bazı davranışları da sergiledikleri saptanmıştır. Çalışmanın sonuçları incelendiğinde Yeşil ve Aslanderen (2017) çalışmasında belirtmiş oldukları ahilik ilkelerinden insanlarla karşılıklı olumlu ilişkiler geliştirmeleri, müşteriyi aldatmaya ve kandırmaya yönelik faaliyetlerden uzak durmaları gerektiği ilkelerine Kapalıçarşı esnaf ve sanatkârlarının uymadıkları sonucuna ulaşılmıştır. Benzer şekilde Akgül (2017)'ün çalışmasından elde ettiği müşteriyle iyi bir iletişim kurma ve müşteriyi önemseme ahilik ilkelerinin Kapalıçarşı esnaf ve sanatkârları tarafından benimsenmediği sonucuna ulaşılmıştır. Bu çalışmanın sonuçları Akgül (2017)'nin çalışmalarının sonuçlarından bu yönüyle farklılaşmaktadır. Soysal ve Tan (2013) çalışmalarında müşterilerle ve diğer işletmelerle olumlu ilişkilerin işletme çalışanları tarafından yürütüldüğünü ifade etmişlerdir. Bu çalışmada esnaf ve sanatkarların müşteriyle olumlu bir ilişki geliştiremedikleri tespit edilmiştir. Bu bakımdan Sosyal ve Tan (2013)'ın sonuçlarından farklı sonuçlar elde edilmiştir. Yerli turistler esnafların bazılarının güler yüzlü ve ilgili olduğunu bazılarının ise güler yüzlü ve misafirperver olmadığını ifade etmişlerdir. Esnafların güler yüzlü ve ilgili olması sonucuyla Soysal ve Tan (2013)'ın çalışmasının sonuçları benzerlik göstermektedir.

Kapalıçarşı' da çok farklı meslek grupları ve farklı kültürde esnafların çalıştığı bilinmektedir. Bu esnafların birlikte dayanışma ve yardımlaşma içinde çalıştıkları söylenebilir. Elde edilen bu sonuç; esnafların Sosyal ve Tan (2013) çalışmasında belirttiği müşterilerle ve diğer işletmelerle olumlu ilişkiler yürüttüklerine ilişkin bulguyla benzerlik göstermektedir. Diğer yandan yardımlaşma ve işbölümü gibi ahilik ilkelerinin olması gerektiğini vurgulayan Karagül ve Masca (2017)'nın çalışmasının sonuçlarıyla da benzerlik söz konusudur. Bu sonuçların tersine Akgül (2017) çalışmasında esnafların esnaf arkadaşa yardım, müşteri yönlendirme ve rekabet konusunda kararsız davrandıklarını belirtmiştir. Bu bakımdan Akgül (2017)'ün çalışmasının sonuçlarından farklı sonuçlar elde edilmiştir.

Esnaf ve sanatkârların kendilerini geliştirmeleri gerektiği ve bazı konularda eğitim alması gerektiği ve geçmiş tarihlerde çıraklık eğitimi vb. eğitimlerin düzenlendiği vurgulanmıştır. Esnaf ve sanatkârların iletişim, satış vb. konularda kendilerini geliştirmeleri ve eğitim almaları gerektiği ifade edilmiştir. Soysal ve Tan (2013) çalışmasında da benzer şekilde işletme çalışanlarının mesleki gelişim ve çevre konularında kendileri geliştirmeleri gerektiği vurgulanmıştır. Yeşil ve Aslanderen (2017)' de bu çalışmanın sonuçlarına benzer şekilde esnaf ve sanatkârların mesleki gelişim ve eğitim konusunda gayret göstermeleri gerektiğini vurgulamışlardır. Genel olarak Kapalıçarşı esnaf ve sanatkârlarının ahilik ilkelerine sahip olmada bazı problemlerin olduğu sonucuna ulaşılmıştır.

Elde edilen sonuçlar doğrultusunda bazı öneriler sunulmuştur.

- Kapalıçarşı esnaf ve sanatkârlarının Ahilik ilkelerini benimsemesine yönelik eğitim programları oluşturulmalıdır.

- Kapalıçarşı esnaf ve sanatkârlarının kurumsallaşması için gerekli eğitim programları düzenlenmelidir.

- $\quad$ Özellikle yerli ve yabancı turistlere yönelik davranışların iyileştirilmesi için iletişim eğitimleri gerçekleştirilmelidir. 
- $\quad$ Aynı işi yapan meslek gruplarının tedarik sürecinden satış ve pazarlamaya kadar ortak kararlar aldığı ve bunun dışında davrananlarla ilgili yaptırımların uygulandığı bir süreç planlanmalıdır.

- Müşterilerin istek ve şikâyetlerinin gerek çevrimiçi gerekse şahsen başvuruları alınarak değerlendirilmesi için istek ve şikâyet yönetim sistemi oluşturulmalıdır.

\section{KAYNAKÇA}

Akça, G. (2003). Ahilik geleneği ve günümüz Fethiye esnafı. Selçuk Üniversitesi Türkiyat Araştırmaları Dergisi, (14), 209-219.

Akgül, D. (2017). Ahilik Kültüründeki Etik İlkelerin Günümüz İşletmelerine Yansımaları: Kırşehir İli Örneği. Ahi Evran Üniversitesi İktisadi ve İdari Bilimler Fakültesi Dergisi, 1(1), 8-26.

Akgündüz, M. (2014). Ticarî hayatta kardeşliği esas alan ahîlik teşkilatı. Harran Üniversitesi Illahiyat Fakültesi Dergisi, 31(31), 9-18.

Akman, M. (2006). Balıkesir yöresinde ahilikten kalma tören ve uygulamalar (Master's thesis, Balıkesir Üniversitesi Sosyal Bilimler Enstitüsü).

Aras, O. N. (2012). Türkiye'de Günümüz İşletmelerinde Ortaklık Kültürünün Tesisinde Ahilik Temel İlkelerinin Yeri ve Önemi (The Role and Importance of the Basic Principles of Akhism Establishing the Culture of Partnership in Today's Business in Turkey). Available at SSRN 2182029.

Arslan, H. (2015). Ahîlik teşkilatı'nın sosyo-iktisadî yapısı ve örneklik değeri. Akademik Bakış Dergisi, 49, 248-271.

Arslan, M. (2010). Ülgener'in dikotomik yönteminde meslek ahlakı ve ahilik. İ. Ü. İlahiyat Fakültesi Dergisi, 1(1), 55-77.

Aslan, H. E. (2013). Türklerde İş Ahlakı ve Geçmişten Günümüze Ahilik. Beykent Üniversitesi Sosyal Bilimler Enstitüsü, Yayınlanmamış Yüksek Lisans Tezi, İstanbul.

Aslanderen, M., ve Yeşil, R. (2016). Esnaf ve Sanatkârların Ahilik Değerlerine Sahiplik Düzeylerinin Değerlendirilmesi. Ahi Evran Üniversitesi Kırşehir Eğitim Fakültesi Dergisi, 17(1), 383400.

Aydın, N. (2015). Ahîlikte İş Ve Ticaret Ahlakının Hz. Peygamber'in Sünnetindeki Temel Referansları. BEÜ İlahiyat Fakültesi Dergisi, 2(1), 87-103.

Aydın, S. (2016). Küreselleşme ve Neo-Liberal Uygulama Sürecinde Sosyal Politika Alanında Ortaya Çıkan Problemlere Çözüm Önerisi: Osmanlı İmparatorluğu'nda Ahilik Sistemi. Kastamonu Üniversitesi İktisadi ve İdari Bilimler Fakültesi Dergisi, 13(3), 40-49.

Aytekin, B., ve Bayramoğlu, S. (2015). İktisat Sosyolojisi Açısından İktisadi Dalgalanmalar ve Krizlere Karşı Tarihsel Bir Çözüm Durağı: Ahi Örgütlenmesi. Internatonal Journal of Academic Value Studies, 1(1), 65-78.

Bayram, S. (2012). Osmanlı Devleti'nde ekonomik hayatın yerel unsurları: Ahilik teşkilâtı ve esnaf loncaları. İstanbul Üniversitesi İlahiyat Fakültesi Dergisi, (21), 81-114.

Bosnalı, Ö. (2004). Ahiliğin Üretim ve Tüketim Mekanizmasındaki Yeri ve Günümüze Uyarlanması. Bolu Abant İzzet Baysal Üniversitesi Sosyal Bilimler Enstitüsü Dergisi, 2(9), 39-46.

Cevherli, F., Cevherli, K., ve Çakmaktaş, B. (2017). Bir Toplumsal Dayanışma Kurumu Olarak Ahîliğin İş Ahlâkına Dair İlkeleri ve Ekonomik Hayata Katkıları. Journal of Current Researches on Social Sciences, 7(1), 307-322. 
Cihangir, İ. S., ve Karakaya, K. (2016). Ahilik Kültürü ve Alış-Veriş Turizmi: Konya Bedesten Çarşısını Ziyaret Eden Turistlerin Algısı Üzerine Bir Araştırma. Nevşehir Hacı Bektaş Veli Üniversitesi SBE Dergisi, 6(2), 110-122.

Cora, İ. (2017). Örgütlerin Yönetimi açısından Ahilik Örgütüne Genel Bir Bakış; Tarihi Bir Araştırma. Karadeniz Sosyal Bilimler Dergisi, 9(16), 251-279.

Çeker, F. (2017). Ahlâkî ve Sosyo-Ekonomik Bir Teşkilât Olarak Ahîlik. Dicle Üniversitesi İktisadi ve İdari Bilimler Fakültesi Dergisi, 12, 84-99.

Çelen, A. İ. (2014). Toplam Kalite Yönetimi'nin Çekirdeği: Ahilik. ODÜ Sosyal Bilimler Araştırmaları Dergisi (ODÜSOBİAD), 4(10), 5-14.

Doğan, H. (2011). Günümüz işletmeleri için ahilik kültüründen örtülü bilginin gelişim ve paylaşım örnekleri. Gümüşhane Üniversitesi Sosyal Bilimler Enstitüsü Elektronik Dergisi, 2(4), 77-100.

Durak, İ., ve Yücel, A. (2010). Ahiliğin Sosyo-Ekonomik Etkileri ve Günümüze Yansımaları. Süleyman Demirel Üniversitesi İktisadi ve İdari Bilimler Fakültesi Dergisi, 15(2), 151-168.

Erbaşı, A. (2012). Ahi Teşkilatında Yönetim Fonksiyonlarıyla İlgili Uygulamalar. Electronic Turkish Studies, 7(2), 1321-1331.

Erbaşı, A., ve Ersöz, S. (2011). Ahilik ve 4c Pazarlama Karması İlişkisi: Tarihî Perspektiften Bakış. Turkish Culture \& Haci Bektas Veli Research Quarterly, 59, 135-146.

Erbaşı, A., Büyükipekçi, S., ve Bakanlar, M. (2010). Türk Dünyası İşletmelerinin Ekonomik Yapılarının Güçlendirilmesinde Ahilik Anlayışından Yararlanılması. Journal of Azerbaijani Studies, 783-798.

Genç, K., Şengül, S., ve Türkay, O. (2016) Ahilik Geleneğinin Destinasyon Çekim Unsuru Olarak Kullanılması: Mudurnu Esnaf Duası Örneği. Uluslararası Osmaneli Sosyal Bilimler Kongresi, Bilecik.

Gündüz, A. Y., Kaya, M., ve Aydemir, C. (2012). Ahilik teşkilatında ve günümüzde tüketicilerin korunmasına yönelik çalışmalar üzerine bir değerlendirme. Afyon Kocatepe Üniversitesi, İ̈BF Dergisi, 14(2), 37-53.

https://www.kulturportali.gov.tr/turkiye/istanbul/gezilecekyer/kapalicarsi 11.02.2021 tarihinde erişilmiş̧ir.

İstanbullu Dinçer, F., ve Kanay, D. (2017). Kapalıçarşı'da Gerçekleştirilen Alışveriş Turizminin Ekonomik Ve Sosyal Etkilerinin Değerlendirilmesi. Sosyal Bilimler Dergisi/Journal of Social Sciences, 1(2), 1-18.

Kantarc1, Z. (2014). An Ethical Business for Social Responsibility and Total Quality Management: Ahı Community Case. Route Educational and Social Science Journal.1(2),177-190.

Kara, A. U., ve Aydoğan, E. (2017). Ahilikte Psikolojik Sermaye Davranışı. Bilig, 80, 217-237.

Karagül, M., ve Masca, M. (2017). Ahilik Düşüncesinin İktisadi Hayata Bakışı ve Kapitalist Sistemle Karşılaştırılması. Afyon Kocatepe Üniversitesi İktisadi ve İdari Bilimler Fakültesi Dergisi, 19(2), 83-91.

Kavi, E. (2015) Ahilik kurumu ve günümüz çalışma yaşamındaki psikolojik sorunlara yönelik çözümler. Hak İş Uluslararası Emek ve Toplum Dergisi, 4(8),110-117.

Mahiroğulları, A. (2011). Selçuklu/Osmanlı Döneminde Kurumsal Bir Yapı: Ahilik/Gedik Teşkilatı ve Sosyo-Ekonomik İşlevleri. Sosyal Siyaset Konferansları Dergisi, (54), 139-154. 
Öztürk, N. (2015). Ahilik Teşkilatı ve Günümüz Ekonomisi, Çalışma Hayati ve İş Ahlaki Açısından Değerlendirilmesi. Dumlupınar Üniversitesi Sosyal Bilimler Dergisi, 7, 1-12.

Serinikli, N. (2017). Kooperatifçilik ve Ahi Birlikleri. Bilecik Şeyh Edebali Üniversitesi Sosyal Bilimler Dergisi, 2(2), 680-689.

Soysal, A. (2013). İşletmelerin Başarısında Ahilik İlke ve Uygulamalarının Önemi: Bir Değerlendirme. Çimento Endüstrisi İşverenleri Sendikası, 27(2), 6-19.

Soysal, A., \& Mehmet, T. (2013). Ahilik ilkelerinin günümüz işletmelerine yansıması: Kilis küçük sanayi sitesi işletmeleri örneği. Niğde Üniversitesi İktisadi ve İdari Bilimler Fakültesi Dergisi, 6(1), 186-202.

Taslacı, N., Sarı, Y. ve Uysal, D. (2016). Sürdürülebilir Kırsal Kalkınmada Milli Bir Model Olarak Ahilik. ISEM2016, 3. International Symposium on Environment and Morality, 4-6 November 2016, Alanya-Turkey.

Uğurlu, K., Aymankuy, Ş. Y., ve Hilmi, A. R. (2015). Turizmde Toplam Kalite Yönetimi Ve Ahilik İlişkisi. Akademik Bakış Uluslararası Hakemli Sosyal Bilimler Dergisi, 52, 310-328.

Ünsür, A. (2017). Ahilik sisteminde ahlak temelli çalışma ilişkileri ve günümüz bakış açısından değerlendirilmesi. Yalova Sosyal Bilimler Dergisi, 7(13), 90-98.

Yeşil, R., ve Aslanderen, M. (2017). Ahilik Değerleri Ölçeğinin Geçerlik ve Güvenirlik Çalışması. Electronic Turkish Studies, 12(4).

Zengin, B. ve Şengel, Ü. (2014). İstanbul Kapalıçarşı Esnafının Turizm Algısı Üzerine Bir Araştırma. XIII. Geleneksel Turizm Paneli 2014, İstanbul.

Zorlu, K., Merdan, E., ve Ege, Ö. (2012). Ahilik Kültürünün Günümüz İşletmelerinde Bilinirliği Üzerine bir araştırma: Gümüşhane örneği. Zeitschrift für die Welt der Türken/Journal of World of Turks, 4(3), 73-94. 